\title{
A BRIEF OVERVIEW OF THE PLIGHT OF COVID-19 ORPHANS IN INDIA AND GOVERNMENTAL INITIATIVES TO TACKLE THE ISSUE
}

\section{DR. ARBAB MOHAMMED ABDUL RUB}

Associate Professor of Law, Department of Private Law, Faculty of Law, University of Bahrain, Kingdom of Bahrain

Covid -19 had a devastating effect on almost every individual in one form or another. The impact is multi-dimensional ranging from increased unemployment, poverty, physical and emotional abuse, economic crisis and still the list is not exhaustive. However, the most devastating effect was on Covid-19 orphans not only in India but across the globe. The plight of Covid -19 orphans is pathetic and worrisome as they are exposed to several vulnerabilities ranging from their schooling, health and diet, and protection and emotional wellbeing.

This research article is analytical in approach and doctrinal method of research is adopted. The present is focused on Covid-19 orphans in India. In this article, various regulatory mechanisms relating to protection of orphans in India and government initiatives to tackle the risks to which the covid-19 orphans are exposed to are highlighted critically evaluated. In the end, conclusions are drawn on the basis of secondary data collected from various newspaper reports and other digital resources and appropriate measures are suggested to help the Covid-19 orphan in India.

Keywords: Covid-19, Orphans' Plight, Regulatory Framework \& Governmental Measures
\end{abstract}

Received: Oct 29, 2019; Accepted: Nov 19, 2019; Published: Nov 30, 2019; Paper Id.: IJPSLIRDEC20198

"Covid orphans are not only living an emotional tragedy, but they are also at high risk of neglect, abuse and exploitation." ---- Yasmin Haque ${ }^{1}$

\section{INTRODUCTION}

Covid has adversely affected many families across India, many children have been left orphaned. Covid-19 orphans are a vital cause of concern but that's the half-truth. The number of orphan children due to the death of a single parent is large and require due care and attention. State governments have started taking efforts for the welfare of India's pandemic orphans, but experts opine that still there is much scope in the concerned area in wake of the risks and vulnerabilities to which Covid-19 orphans are exposed and the increasing number of orphans amid pandemic.

According to various ministerial and media reports, the number of Covid-19 orphans is increasing with each passing day. According to The Ministry of Women and Child Development (WCD) since April 2021 till 25 May 2021577 children were orphaned across India. As per NCPCR statement in the Supreme Court, 3,621 children were orphaned, 274 were found abandoned and 26,176 lost either parent during the period ranging from

\footnotetext{
${ }^{1}$ UNICEF India's chief
} 
April 1, 2020 till June 5, 2021.2

As per NCPCR data, 9,346 children were abandoned or lost one or both parents between April 2020 and May 29, 20213, out of which merely $364(3.9 \%)$ were either in the shelter homes, orphanages or under the care of "special adoption agencies", but greater number off $(96.1 \%)$ were in custody of a guardian or family member of the surviving parent, whereas only $140(1.4 \%)$ were classified as "abandoned". There has not been a significant surge in the figure of children needful of care and support due to both parents passing away from the pandemic, according to the staff of state-run adoption centers and the nongovernmental organizations working on child welfare ${ }^{4}$.

\section{PLIGHT OF COVID-19 ORPHANS IN INDIA}

\section{Loss of Parental Care}

Children living on the street without family care or other alternative care are deprived of their liberty are exposed to more vulnerabilities under the present scenario. Large waves of pleas are looming on social media seeking help for such children.

"Need a breast milk donor for a one-day-old baby in Delhi. Her mother passed away due to COVID," one Tweeter tweeted ${ }^{5}$. Children are exposed to toxic stress ${ }^{6}$. The orphans are forced to stay in temporary homes, suffering from anguish, solitude, misfortune, and are quite prone to developing post-traumatic stress disorder. ${ }^{7}$ This stress on children during their seminal growth years can affect their self-esteem and decision-making abilities forever..

\section{Increased Risks of other Vulnerabilities}

Risk of exposure to other vulnerabilities like violence, exploitation and abuse are on the rise for Covid-19 orphans. According to Delhi High Court bench ${ }^{8}$ orphanage either due to loss of single or both parents expose them to vulnerabilities. ${ }^{9}$ Children whose parents have died or are sick are compelled to adopt tedious works ${ }^{10}$. Warning was issued by union government's minister ${ }^{11}$ that unofficial approaches to adopting COVID-19 orphans are tricks and are illegal. ${ }^{12}$ Many Orphans have been left abandoned. The states of Maharashtra, Uttar Pradesh and Rajasthan have the highest number of orphaned children, as they lost either a single parent, both the parents or were abandoned during the COVID-19

\footnotetext{
${ }^{2}$ B. Abraham, 'The Number Of COVID-19 Orphans Are Increasing and They Are Easy Targets for Human Traffickers', Jun 12, 2021, www.indiatimes.com/news/india/covid-19-orphans-are-increasing-and-they-are-easy-targets-for-humantraffickers-542499.html July 7, 2021 4:18 P.M IST

${ }^{3}$ Source: National Commission for Protection of Child Rights' affidavit to the Supreme Court on May 30, 2021

${ }^{4}$ S.Khaitan, 'What Calls For Adopting 'Covid Orphans' Are Missing', June 2, 2021 www.indiaspend.com/covid-19/whatcalls-for-adopting-covid-orphans-are-missing-752632 July7 ,2021 4:06 PM IST

${ }^{5}$ R.Sethuraman, N. Bhattacharjee \& C. Monnappa, 'Pleas for help in India as COVID-19 leaves children without carers' May 6, 2021 www.reuters.com/world/india/pleas-help-india-covid-19-leaves-children-without-carers-2021-05-06/ July 8,2021 3:05PM IST

${ }^{6}$ Araújo LA, Veloso CF, Souza MC, Azevedo J.M, Tarro G. 'The potential impact of the COVID-19 pandemic on child growth and development: a systematic review'. J Pediatr (Rio J). 2020. doi.org/10.1016/ July 8,.2020

7 Mahajan, Charu MD, DM; Kapoor, Indu MD; Prabhakar, Hemanshu MD, PhD 'Psychological Effects of COVID-19 on Children of Health Care Workers', Anesthesia \& Analgesia: September 2020 - Volume 131 - Issue 3 - p e169-e170 Doi: 10.1213/ANE.0000000000005034

${ }^{8}$ The Delhi High Court bench of Justices Vipin Sanghi and Jasmeet Singh

${ }^{9}$ www.news 18.com/news/india/loss-of-parents-puts-kids-in-vulnerable-situation-hc-asks-delhi-govt-to-gather-info-onorphans-3807911.html July8, 2021

${ }^{10}$ Protsahan India Foundation, a child rights NGO

${ }^{11}$ Smriti Irani India's minister for women and child development

12 Al Jazeera, 'COVID causes orphan crisis in India; experts fear neglect, abuse', www.aljazeera.com/news/2021/5/20/ May 20, 2021
} 
pandemic. ${ }^{13}$ Indian social media is ubiquitous by calls for temporary homes or meals for children left alone at home or roaming in the hospital as their loved ones are in the critical care unit. ${ }^{14}$ Orphaned girls may become victims of child marriages.

\section{Deprivation of Education and Increased Danger of becoming Child Laborers}

With the closing of schools and subsequent seclusion, children who are victims of violence at home or online fail to get help, due to their separation from teachers, social service workers and other crucial support mechanisms. Collaterally they may start suffering from additional stress and stigma that forces them to take up work for satisfying the basic necessities of family. With closure of schools in India since March 2020 amid the pandemic, education has suffered a huge loss. The underprivileged orphans find it difficult to gain access to education and to fill the gap via online education as most of them do not have digital access and are not able to continue their studies and thereby will prefer to opt for offering their services as child laborer. Child rights groups fear that traffickers who approach them with a promise to help them financially or to get a job might force them into becoming child labors ${ }^{15}$.

\section{Trafficking Fears}

Orphaned children are mainly susceptible to trafficking and other forms exploitation like forcible begging, or child labor. ${ }^{16}$ There are apprehensions that covid-19 orphans in India can be exploited for cheap manual labor or even as sex workers. ${ }^{17}$ Amid the foresighted threats of child trafficking and illegal adoption during the course of pandemic several genuine tragedies have been noticed by the child rights activists. ${ }^{18}$ The aim of traffickers may range from begging, sex workers, child pornography, bonded laborers or even organ harvesting scandals,. ${ }^{19}$

\section{Legal Framework to Protect the Orphans in India}

In India, there are certain laws at the domestic level to protect the rights of orphans such as:

\section{- The orphanages and other charitable homes (supervision and control) Act, 1960}

The object of this act is to provide supervision and control of orphanages, homes for neglected women or children. Generally, the plight of Orphans living in orphanages is very pitiful as they are deprived of certain essential rights such as right of dignity, movement etc. ${ }^{20}$

\section{- Juvenile Justice Act 2015}

\footnotetext{
${ }^{13} \mathrm{~A} . K r i s h n a$, 'Three states have the most children in distress due to COVID-19: NCPCR', news.careers360.com/covid-19coronavirus-children-orphaned-abandoned-maharashtra-up-rajasthan-narendra-modi-sonia-gandhi-ncpcr-delhi-govt-westbengal June10, 2021

${ }^{14}$ R.MOHAN, 'As parents succumb to Covid-19 in India, children are in distress', 'The Straits Times' May 9, 2021

${ }^{15}$ Supra note 2

${ }^{16}$ P. Kundu, 'COVID-19 Crisis Will Push Millions of Vulnerable Children into Child Labor', The Wire April 21, 2020

${ }^{17}$ V.Pandey \& A.Clarance, 'Coronavirus: The Indian children orphaned by Covid-19', BBC News www.bbc.com/news/world-asia-india-57264629

${ }^{18}$ R. K Singh and O. Frederick, 'Child trafficking suspected behind pleas for adoption of Covid 'orphans' Hindustan Times

${ }^{19}$ R. Krishnen, 'On World Day Against Trafficking in Persons, a look at the numbers in India', July 30, 2020 theprint.in/ July9,2021 11:32AM IST

${ }^{20}$ Meena, Devnarayan, Legal Rights of Orphan Children in India-An Attempt to Study the Role of Society (July 31, 2020). Available at SSRN: ssrn.com/abstract $=3665383$ or dx.doi.org/10.2139/ssrn. 3665383
} 
According to section 2(14) of this Act, any orphaned child who is minor can be declared legally free for adoption if he is without biological or adoptive parents or legal guardian; or if his legal guardian is not ready to take, or capable of taking care of the child. As per the Act, even the child's relatives such as paternal/maternal uncle or aunt, paternal/ maternal grandparents need to legally adopt the child, once the CWC declares the Child as 'legally free' for adoption ${ }^{21}$. According to Section 80 and $81^{22}$ sharing of posts on social media or other such platforms are prohibited even the sale and purchase are punishable offences ranging from three to five years in jail or Rs. 1 lakh in fine.

\section{- (CARA) The Central Adoption Resource Authority}

A statutory body that works under the Ministry of Women and Child Development is the nodal agency for adoption. - this body regulates the adoption of orphaned, abandoned and surrendered children through its associated or recognized agencies ${ }^{23}$. In India adoptions are permissible only through authorized agencies recognized by CARA or SARAs (The State Adoption Resource Authority) this provision can save the orphans from the clutches of human traffickers under the pretext of adoption. ${ }^{24}$.

Besides the above, there are several other protective mechanisms to protect the Covid-19 orphans at the national and international levels.

\section{The United Nations Convention on the Rights of the Children (UNCRC) 1992}

The rights as described in the Convention include

- $\quad$ Article $7 \&$ Article 8- The Right to and Identity

- $\quad$ Article 23 \& Article 24- The Right to Health

- $\quad$ Article 28-The Right to Education

- Articles 8, 9, 10, 16, 20, 22 \& Article 40- The Right to a Family Life

- Article 19 \& Article 34- The Right to be protected from violence

- Article 12 \& Article 13 The Right to an opinion

- Article 38\& Article 39- The Right to be protected from armed conflict

- Articles 19, 32, 34, 36 \& Article 39-The Right to be protected from exploitation

\section{Hague Adoption Convention}

An international treaty which provides important safeguards for protection of the best interests of children, their biological parents, and adoptive parents for inter-country adoptions, but India is not a signatory to it.

\footnotetext{
${ }^{21}$ S.Rani, 'An overview of adoption laws in India' May 1, 2020 lawtimesjournal.in/an-overview-of-adoption-laws-in-india/ July 9, 2021 12:05 PM IST

22 Juvenile Justice (JJ) Act, 2015

${ }^{23}$ www.latestlaws.com/bare-acts/central-acts-rules/children-laws/central-adoption-resource-authority-cara/ July 9,2021 1:01PM IST

24 cara.nic.in/Regulation/CARA.html
} 


\section{State Government's Initiatives to Protect the Rights of Orphaned During the Pandemic}

India is a federal state and as per doctrine of separation of powers various state governments have come up with certain initiatives to tackle the problems of covid-19 Orphans. The chief among them include:

\section{Uttar Pradesh (U.P)}

Several schemes have been initiated for covid-19 orphans such as U. P Mukhyamantri Bal Seva Yojana - under this scheme initiatives will be taken for the systematic upbringing and education of Covid-19 orphans, monthly financial assistance of Rs 4,000 will be provided to guardians or custodians of Covid-19 orphans till they become adult, those orphans who do not have any caretaker or guardian will be under the care of child protection homes. Free education facility will be provided in Vidyalaya ${ }^{25}$ and school ${ }^{26}$. Under the Abhyudaya Yojana- laptops and tablets will be given to Covid-19 orphans to facilitate higher studies in addition to financial assistance of Rs 1, 01,000 for the marriage of girls ${ }^{27}$.

\section{Delhi}

The government has announced free education forCovid-19 orphans. Steps are being taken for identifying the orphans and follow up is taken with the necessary measures for the welfare of such destitute is done such secure. ${ }^{28}$

\section{Himachal Pradesh}

The caregivers of such orphans are being assisted with Rs 2,500 per month till the child turns 18. Efforts are also taken for rehabilitation of such children.

The Madhya Pradesh Government is allowing Covid-19 orphans free admission in private schools and Rs 5,000 monthly pension. ${ }^{29}$

The Andhra Pradesh government Covid orphaned will get Rs. 10 lakhs deposited in their bank account. They will get a monthly interest of about $R s .5,000$. When the child turns 25 , they can take the capital amount.

In Kerala, the government has identified nine such orphans, and made an announcement that they will be provided a special package of $R s .3,00,000$ as immediate relief along with a monthly deposit of $R s .2,000$ till they turn 18 . Apart from the above, even the educational expenses of such children will be beard by the state till graduation. ${ }^{30}$

\section{Karnataka Government has Initiated -Bal Seva Scheme}

Under this scheme, the covid-19 orphans will be able to receive Rs 3,500 monthly and those who are under 10 years of age will be able to avail free education in a residential school. Orphaned or abandoned girl-child due to COVID-19 will also

\footnotetext{
${ }^{25}$ Kasturba Gandhi Balika

${ }^{26}$ Atal residential

${ }^{27}$ Lucknow University to adopt Covid orphans June 16, 2021 www.indiatvnews.com/ July7, 2021 3:54 PM IST

${ }^{28}$ Editorial in Tribune India "Protect Covid Orphans-Taking care of such vulnerable kids a challenge" www.tribuneindia.com/news/ July 7,2021 4:00 P.M IST

${ }^{29}$ M.Deka, 'Madhya Pradesh to Allow Children Orphaned by Covid to Apply for Free Admission in Schools', www.ndtv.com/education/madhya-pradesh-allow-children-orphaned-covid-apply-for-free-admission-in-schools July 7 , 2021 4:08 PM IST

${ }^{30}$ Edited by Harish Pullanoor, written by S. Chakravarty, 'Losing Parents to Covid, Orphaned Children Need Emotional, Financial Help', special.ndtv.com/justice-for-every-child-87/news-detail/losing-parents-to-covid-orphaned-children-needemotional-financial-help-2451486/3 July 7, 2021 4:12 PM IST
} 
get Rs 1 lakh as financial assistance ${ }^{31}$.

The Maharashtra government is depositing fixed deposits of Rs five lakh in the name of Covid-19 orphaned children in the form of FD with interest after attaining the age of 21 years. Those who have lost at least one parent to COVID-19 will also get a monthly allowance of Rs $1,125^{32}$.

Besides these several financial support measures have been announced for orphaned children from the PM Cares Fund, Ministry of Women and Child Development ${ }^{33}$.

\section{Other Initiatives}

The National Commission for Protection of Child Rights (NCPCR) has introduced 'Bal Swaraj portal, in wake of the pandemic, the link has been extended to Bal Swaraj Covid - care ${ }^{34}$. The Principal Secretaries of states and union territories are obliged to upload the information on the portal and it will assist to digitally monitor and track those children who are in need of care and protection. The Commission (NCPR) will be able to recognize whether the child has been produced before the Child welfare commissioner CWC and if the orders are being passed for him/her. It will facilitate in identifying the State that is in need of financial assistance and funds for the sake of Covid-19 orphans ${ }^{35}$.

Sensitizing Action on Mental Health Vulnerability through Emotional Development and Necessary Acceptance $^{36}$ - National Commission for Protection of Child Rights (NCPCR) has started Tele-Counseling through a TollFree Helpline for children through SAMVEDNA (Sensitizing Action on Mental Health Vulnerability through Emotional Development and Necessary Acceptance); in order to provide psychological and emotional support to children affected during Covid-19 Pandemic. The counseling is done with the help of trained and qualified Experts/through different Tele counseling strategies ${ }^{37}$.

\section{Judicial Response with Respect to Orphans Rights}

The National Commission for Protection of Child Rights (NCPCR) had appealed to the Apex Court to mediate in the matter of illegal adoption taking place in the backdrop of the pandemic. Taking cognizance of the matter The Hon'ble Supreme Court has given several suggestions ${ }^{38}$ for the protection of Covid-19 orphans. Such as: After receiving the information relating to guardian's willingness to take care of orphan The DCPO (District Child Protection Officer) should meet the child and the guardian immediately and make assessment of the immediate basic needs of the child and the financial condition of the guardian. DCPO should provide financial assistance of Rs 2000 monthly in tune with the Integrated Child Protection Scheme (ICPS). Proper arrangements must be made to ensure that the orphan gets assistance to complete their education and even their right to property must be protected. Due care must be taken to prevent illegal

\footnotetext{
${ }^{31}$ Madur, 'Bal Swaraj and Bal Seva Schemes for The Welfare of Children Orphaned by COVID-19', www.karnataka.com/govt/ July 13,2021 11:04AM IST

32 The Economic Times June 20,2021

${ }^{33}$ S.C.Pandey, 'Covid orphans must be a priority care group', June 18, 2021 www.dailypioneer.com/2021/columnists/covid-orphans-must-be-a-priority-care-group.html July7,2021 3:57PMIST ${ }^{34}$ pib.gov.in/PressReleaselframePage.aspx? PRID $=1722677$

35 Covid Orphaned 1,742 Children, 7,464 Lost One Parent, NCPCR Told SC outlook web Bureau June 1, 2021 www.outlookindia.com/website/story/india-news-covid-9300-children-lost-parents-or-were-abandoned-during-pandemicJuly 7, 2021 4:17PM IST

${ }^{36}$ www.pib.gov.in/PressReleasePage.aspx?PRID=1719426

${ }^{37}$ Ibid

${ }^{38}$ SCC Online SC 422, order dated 07.06.2021
} 
adoptions ${ }^{39}$.

\section{Challenges Ahead}

There are certain orphans whose parents have bank balance plus insurance policies death certificates of parents are not yet generated and these orphans may not be able to access the same. Hence there is urgent necessity to address the issue and build a mechanism to rehabilitate the orphans and to ensure their insurance and bank policies don't lapse." ${ }^{40}$

Some new born infants have become orphans as they have lost their mothers and availability of neo natal care placements and the ability of service providers to adequately meet children's care is a great task. The data which is available with UNCR is not exhaustive the number of unregistered orphans may be more and may have not been registered over the portal. Will the government incentives reach the beneficiaries or some middle man will reap the fruits as in cases of natural calamities in past the relief measures never reached the beneficiaries? Another challenge is availability of resources to fulfill the required obligations towards orphans as the Pandemic has hit the economy of states as well as union territories very hard. Despite having several legislations for protection of children the rate of crime against children are multiplying in numbers due to lack of proper implementation mechanism and indeed it is a great challenge.

\section{CONCLUSIONS}

Death of parents leaves deep scars on children's soul as it deprives children not only of their presence but exposes them to innumerable challenges and makes them dependent on relatives. Children are an important national asset, and for the development of a nation, children's development is crucial. The deadly pandemic has unnerving scary challenge of ensuring the safety of orphaned children and the protection of their health, educating safety, rights and inheritances. There is no dearth of regulatory mechanisms at the national and state level to combat the upcoming challenges still there are some policy considerations that need to be addressed on a priority basis for the sake of protecting the future asset of India that is children. Different states have initiated different measures to address the issue there is no uniformity and this may pose another challenge what if the one parent of the child is from one state and another from another state which state's incentives those children will be entitled to? What about those children who are already leaving on the streets and have become orphans due to deadly pandemic?

\section{SUGGESTIONS}

One nation one policy must be adopted for all orphans in India with reference to their educational, health and other benefits. Individual, family and community sponsorship must be rolled out immediately for COVID affected children and their families. There is an urgent necessity of creating temporary child and infant care shelters for covid-19 orphans and children whose parents are suffering from Covid-19, as they are in need of extra care and protection during such period. Orphaned and abandoned Children's safety must be the utmost priority of every individual who is empowered with enough physical and economic amenities to deal with the same.

The international community must come together today and agree upon an international restoration policy and action plan post COVID-19 with a focus on the protection, health and education of Covid- 19 orphan. Budgetary

\footnotetext{
${ }^{39}$ Ibid

40 P.Ghosh, Government Springs into Action to Help Covid Orphans, Protect Them from Trafficking Trap May 24,2021 www.news18.com/news/india/government-springs-into-action-to-help-covid-orphans-protect-them-from-trafficking-trap3770414. Html July 9, 2021 3:49 PM IST
} 
allocations must be enhanced and Philanthropists should allocate some sort of monetary help as a relief measure especially for Covid-19 orphans.

Special efforts should be taken to identify children orphaned due to COVID-19 but have not yet been registered over the Bal Swaraj Covid-care Portal. Priority should be given to making arrangements for shelter and foster care for these orphans.

\section{REFERENCE}

1. SMWP No. 4 of 2020 In Re. Contagion of Covid-19 virus in Children Homes

2. The Bal Swaraj Portal Website: ncpcr.gov.in/baalswaraj

3. Juvenile Justice (Care and Protection of Children). Act, 2015

4. The Economic Times

5. The Straits Times'

6. www.news18.com

7. www.indiatimes.com

8. $w w w . n d t v . c o m /$

9. www.outlookindia.com/

10. www.pib.gov.in/PressReleasePage.aspx

11. www.dailypioneer.com/

12. Tribune India

13. Law Times Journal.

14. BBC News www.bbc.com/

15. The Wire

16. Hindustan Times

17. The Economic Times

18. theprint.in/

19. SSRN: ssrn.com/abstract

20. Al Jazeera, www.aljazeera.com/

21. news.careers360.com/

22. 'The Straits Times'

23. Anesthesia \& Analgesia

24. www.indiaspend.com

25. www.reuters.com

26. United Nations Convention on the Rights of the Child 


\section{Governmental Initiatives to Tackle the Issue}

27. The United Nations Convention on the Rights of the Children (UNCRC) 1992

28. The orphanages and other charitable homes (supervision and control) Act 1960 legislative.gov.in

29. Hague Convention on Protection of Children and Cooperation in respect of Inter-Country Adoption International Covenant on Civil and Political Rights

30. The National Commission for Protection of Child Rights (NCPCR) www.ncpcr.gov.in

31. Central Adoption Resource Authority cara.nic.in/Parents/eg_ri.html

32. www.outlookindia.com

33. SCC on Line

34. www.dailypioneer.com

35. www.latestlaws.com

36. www.news.careers360.com

37. www.indiatimes.com

\section{REFERENCES}

1. J. Sengendo, J.Nambi. The psychological effect of orphanhood: a study of orphans in Rakai district. Health Transit Rev. 1997; 7 Suppl:105-24. PMID: 10169639.

2. D. N. Mutisoand Dr. P. M. Mutie, Challenges Affecting Orphans and Vulnerable children (Ovcs) In Embu County, International Journal of Sociology Vol.1, Issue 1pp 18-36, 2018www.iprjb.org17

3. N Dalen, A.J. Nakitende, \& S.Musisi, They don't care what happens to us. The situation of double orphans heading households in Rakai District, Uganda. BMC Public Health 9, 321 (2009). doi.org/10.1186/1471-2458-9-321

4. F Jaqualine Mangoma, J Moses Chimbari \& E Dhlomo (2008) An enumeration of orphans and analysis of the problems and wishes of orphans: the case of Kariba, Zimbabwe, SAHARA-J: Journal of Social Aspects of HIV/AIDS, 5:3, 120-128, DOI:10.1080/17290376.2008.9724910

5. Carme Montserrat; Marta Garcia-Molsosa; Joan Llosada-Gistau (et al.), The views of children in residential care on the COVID-19 lockdown: Implications for and their well-being and psychosocial intervention, Journal: Child Abuse \& Neglect, 2021

6. Chih Lin; Shih-Ming Chu; Jen-Fu Hsu (et al.), Delivery management of suspected or confirmed COVID-19 positive mothers, Journal: Pediatrics \& Neonatology 2021

7. April N. Terry; Ashley Lockwood; Morgan Steele (et al.) The gendered path for girls in rural communities: the impact of COVID-19 on youth presenting at juvenile detention facilities 2021 Journal: Crime \& Delinquency

8. https://www.unicef-irc.org/covid19?utm_source=unicefinnocentihomepage\&utm_campaign=covid19

9. Holt, M. I. (2001). Indian Orphanages. United Kingdom: University Press of Kansas.

10. The Volume-I (Main Report) of the Report of the Committee for: Analysing Data of Mapping and Review Exercise of Child Care Institutions under the Juvenile Justice (Care and Protection of Children) Act, 2015 and Other Homes Posted: 2018

11. The United Nations Guidelines for the Prevention of Juvenile Delinquency (Riyadh Guidelines), 1990

12. The United Nations Rules for the Protection of juveniles Deprived of their Liberty Posted: 1990 
13. The United Nations Standard Minimum Rules for the Administration of Juvenile Justice Posted: 1985

14. United Nations General Assembly Session 14 Resolution 1386. Declaration of the Rights of the Child A/RES/1386(XIV) The United Nation Convention on the Rights of the Child Posted: 1959

15. Hague Convention on Protection of Children and Cooperation in respect of Inter-Country Adoption International Covenant on Civil and Political Rights, volume 3 Posted: 1966

16. Declaration of the Rights of the Child (Adopted by UN General Assembly Resolution 1386 (XIV) of Posted: 1959-12-10

17. Nguyen, Dongthi Thao, and Thu Chung Kieuthi. "New Trends In Technology Application In Education And Capacities Of Universities Lecturers During The Covid-19 Pandemic." International Journal of Mechanical and Production Engineering Research and Development (IJMPERD)10 : 1709-1714.

18. Almetwally, Ehab M., and M. I. Gamal. "Discrete Alpha Power Inverse Lomax Distribution with Application of COVID-19 Data." International Journal of Applied Mathematics \& Statistical Sciences (IJAMSS) 9: 11-22.

19. Singh, Brijesh P. "Modeling and Forecasting Novel Corona Cases in India Using Truncated Information: A Mathematical Approach." International Journal of Applied Mathematics \& Statistical Sciences 9.4 : 13-24.

20. Sirisha Deepthi Sornapudi \& Meenu Srivastava, "Face Mask For Covid-19: A Social Responsibility”, International Journal of Agricultural Science and Research (IJASR),Vol. 10, Issue 3, pp, 1-6 